Article

\title{
Unraveling the Bankruptcy Risk-Return Paradox across the Corporate Life Cycle
}

\author{
Minhas Akbar ${ }^{1}\left(\right.$, , Ahsan Akbar ${ }^{2, *}$, Petra Maresova ${ }^{3}\left(\mathbb{D}\right.$, Minghui Yang ${ }^{2}(\mathbb{D}$ \\ and Hafiz Muhammad Arshad ${ }^{1}$ \\ 1 Department of Management Sciences, COMSATS University Islamabad (Sahiwal Campus), Sahiwal 57000, \\ Pakistan; minhasakbar@cuisahiwal.edu.pk (M.A.); hmarshadphd@cuisahiwal.edu.pk (H.M.A.) \\ 2 International Business School, Guangzhou College of South China University of Technology, \\ Guangzhou 510080, China; yangmh@gcu.edu.cn \\ 3 Department of Economy, Faculty of Informatics and Management, University of Hradec Kralove, \\ Rokitanskeho 62/26, 50003 Hradec Kralove, Czech Republic; petra.maresova@uhk.cz \\ * Correspondence: akbar@gcu.edu.cn
}

Received: 31 March 2020; Accepted: 24 April 2020; Published: 27 April 2020

check for updates

\begin{abstract}
Bankruptcy risk is a fundamental factor affecting the financial sustainability and smooth functioning of an enterprise. The corporate bankruptcy risk-return association is well founded in the literature. However, there is a dearth of empirical research on how this association prevails at different stages of the corporate life cycle. The present study aims to investigate the bankruptcy-risk relationship at different stages of corporate life cycle by employing Hierarchical Linear Mixed Model (HLMM) regression estimation on the data of listed non-financial Pakistani firms from 12 diverse industrial segments. We grouped the firms into introduction, growth, mature, shake-out, and decline stages of the life cycle using Dickinson's model. Empirical results assert that corporate risk-taking at the introduction stage yields superior financial performance in the future, while risk at the growth stage positively contributes to a firm's current performance. Moreover, because of risk-averse and non-diversified managerial behavior, bankruptcy risk at the mature stage is negatively associated with both current and future performance. Likewise, risk-taking at the decline stage has significant negative implications for firm performance as the managers of such firms undertake heavy investments in a turnaround attempt; however, owing to the risk-averse behavior, they may indulge in negative net present value (NPV) projects. The study findings imply that managers synchronize a firm's risk exposure with the corresponding life cycle stage to avoid going bankrupt. Moreover, excessive risk-taking during the mature and decline stages can considerably harm the financial sustainability of an enterprise. Hence, investors should exercise a degree of caution when investing in highly indebted later-stage (mature and decline) firms. Overall, bankruptcy risk-return resembles an inverted U-shaped relationship. Our results are robust and can apply to various econometric specifications.
\end{abstract}

Keywords: bankruptcy risk; financial sustainability; corporate life cycle; nonfinancial firms; Pakistan

\section{Introduction}

Sustainability is a broad concept applicable to almost every aspect of our planet since its inception. However, since the emergence of various environmental, social, and economic issues in the past few decades, sustainability has become the focal area of research among practitioners and academicians alike. In the business world, Corporate Financial Sustainability (CFS) has been considered one of the major challenges faced by financial managers. Although there is no standard definition of CFS, in general it is "being able to be there for your beneficiaries in the long term. It is the opposite of 
having to cease your activities simply because you have run out of money" [1]. In simple words, a firm will be considered financially sustainable if its operations do not shut down even if external funding is suspended. Therefore, it is imperative for financial managers to keep a close eye on a company's financial distress/bankruptcy risk level and its impact on corporate returns. Failing to do so may result in either a lower return on investments for shareholders or the actual bankruptcy of the firm.

The concept of the Corporate Life Cycle (CLC) has attracted considerable interest in the last few decades as a conceptual model to understanding various aspects of corporate development $[1,2]$. The CLC theory entails that firms pass through a sequence of development phases and that the structures and policies of the enterprise vary considerably with changes in its development stage $[3,4]$. Numerous empirical studies have explored the relationship between corporate life cycle stages and firm financing decisions [5], growth [6], bankruptcy risk [7], market performance [8], investment [9], and dividend payment policies [10]. Moreover, after the recent credit crunch of 2007-8, firms' bankruptcy risk has emerged as a hot topic in the corporate finance literature as it has significant ramifications for the sustainable operations of the firm [11]. Bankruptcy or insolvency risk refers to a state of business where a firm faces difficulty paying its debt obligations; if this state of financial distress gets prolonged, it may lead to actual insolvency. Studies on bankruptcy risk predominately focus on the development of models that may predict the probability of firms filing for bankruptcy. Researchers contend that insolvency risk has a significant influence on a firm's investment choices [12], stocks and bond earnings [13,14], efficiency [15], dividend disbursements [16], and operational composition [17].

The U.S. financial crisis of 2008-2009 brought about a renewed focus on bankruptcy risk as it can significantly influence the survival and growth prospects of firms. However, there is no consensus on how bankruptcy risk affects an enterprise's present and future performance. Over the years, studies on corporate risk-taking and future financial performance have provided varying outcomes. Most firms are risk-averse and do not assume more risk unless risk-taking delivers considerable expected future returns $[18,19]$. Aaker and Jacobson [20] revealed a positive association between risk-taking and corporate performance. Fiegenbaum and Thomas [21] observed that, in a few industrial sectors, risk and firm performance have a positive association, while in others there is a negative association. On the contrary, [22-24] found a negative relationship between risk-taking and corporate performance, mainly for below-average performers. Following his prior research, Bowman [25] explored a positive link between risk and return for 1965 to 1969. However, the period of 1970-1979 revealed a strong negative association for the risk-return paradox. After the seminal works by [22,25], which, contrary to economic theory, suggested a negative association between risk and return, a long list of researchers probed this stream of inquiry. They came up with varying rationales to vindicate this negative association. These can be broadly divided into three categories: 1) contingent events that influence managerial attitude towards risk; 2 ) strategic conduct that creates differences in performance; and 3) statistical artifacts [26].

However, unlike in prior studies, we argue that this risk-return puzzle could be a function of corporate life cycle stages. The entrepreneurial activity approach postulates that markets pass through continuous changes and create profit-making opportunities for organizations that are capable and responsive [27]. Likewise, organizations evolve through different stages of the life cycle and tend to adjust their entrepreneurial strategy to suit the varying market requirements in order to capitalize the profitable opportunities [28]. The evidence suggests that CLC stages can play an important role in solving the bankruptcy risk-return puzzle. So far, there is a serious lack of empirical research that examines the bankruptcy risk-return relationship through the lens of CLC stages. Therefore, the present study aspires to fill this void in the literature and unravel the role of corporate life cycle stages in influencing the bankruptcy risk-return association. To a limited extent, our study is related to the work of Henderson and Benner [29], who found that the risk-return relationship evolves from positive to negative as a firm ages.

However, the present study is distinct in a number of ways. First, Henderson and Benner [29] used firm age as a measure of its life cycle stages, which is a sequential measure. Khan and Watts [30] 
assumed that organizations develop sequentially throughout their life cycle, while ignoring the fact that the nature of the life cycle can be nonsequential [31]. Certainly, these sequential measures have been denounced because of their linear application and unsuitability in the real corporate scenario (see, e.g., [32]). To overcome this issue, we follow Dickinson's (2011) model to measure CLC stages. She proposes a cyclic measure of corporate life cycle grounded on the cash flow patterns of an enterprise. Second, unlike Henderson and Benner [29], who used gains and losses as a measure of risk, our focus is on the bankruptcy risk of firms. Another relevant work is by Habib and Hasan [33]. They examined the association between firm performance and firm earnings (standard deviation of ROA and returns) based on risk proxies at different stages of CLC. However, the present study centers on bankruptcy risk and the associated firm's current and future performance conditional on CLC stages. Thus, the uniqueness of the current research lies in the fact that it is the first empirical attempt to examine the association between one of the most crucial types of risk (bankruptcy risk) at various stages of CLC and firm performance.

The contribution of this research is twofold. First, we categorize firms into various stages of CLC and use HLMM regressions that can process multilevel data when observations are not completely independent. Second, we provide new evidence about the relevance of corporate life cycle model on the bankruptcy risk-return association. The empirical results reinforce the fact that the bankruptcy risk-return relationship varies at different stages of CLC. Thus, practitioners and policymakers can only devise optimal capital structure plans by taking into consideration the corresponding stage of CLC to ensure the sustainable functioning of an enterprise.

Rest of the article is organized as follows. Section 2 constitutes the literature review and hypothesis development. Section 3 outlines research design. Empirical findings and discussion are reported in Section 4 , while Section 5 concludes the study.

\section{Literature Review, Theoretical Underpinning, and Hypothesis Development}

The literature on corporate risk-taking and firm performance yields inconsistent outcomes. While proponents of the post-Bowman paradox $[22,23,25]$ tried to uncover the underlying factors that explain a negative risk-return association, the prospect theory of Kahneman and Tversky [34] conjectures that managerial risk-taking preferences are dynamic, so troubled firms make hasty decisions in a turnaround attempt and to recoup losses. Furthermore, Bromiley [35] posits that poorly-performing (decline stage) firms not only take more risks, but also invest in risky gambles with lower anticipated returns. Following the prospect theory, it is plausible to maintain that early-stage firms (introduction and growth stage) have more avenues to invest in positive NPV projects, and their sales grow rapidly, which contributes to firm profitability. However, once the sales level stagnates (maturity stage), managers start to invest in long shots that further deteriorate firm performance (decline stage).

Furthermore, in a more recent study, Akbar et al. [7] revealed that introductory firms face higher bankruptcy risk with heavy financing costs because of the information asymmetry. Likewise, Liao [36] suggests that new entrants usually face negative returns because of less efficient production processes and limited access to financial resources. Hence, risk-taking at the early stage of the life cycle yields poor performance [33]. However, over the course of time, younger firms learn to avoid losses [29]. Start-up firms require higher investment in plants and equipment and thus have more options to undertake investments in positive NPV projects [37]. However, heavy investment in capital assets and capacity building at the introduction stage may result in poor current performance. Once the opportunity is properly capitalized, such firms will enjoy substantial profitability in the future. This was confirmed by Navaretti et al. [38]: in a sample of firms from three European countries (France, Italy, and Spain), they found that young firms perform better than older firms.

Growth-stage firms focus on research and development, capacity building, and advertisement to distinguish their product line from competitors, which results in higher profit margins [39]. Furthermore, growth firms focus on rapid sales growth, which boosts firm performance [3]. Ultimately, a risk-reward balance could be attained between the growth and maturity stages of the life cycle [1]. Yazdanfar and 
Öhman [40] used panel data from 26,721 Swedish small to medium enterprises (SMEs) for 2008-2011 and observed that firms at their introduction and growth stage perform better than mature firms.

Lester and Parnell [41] posit that, owing to the hierarchical and bureaucratic structure of mature firms, introducing structural changes becomes difficult, which increases the likelihood of poor performance during the maturity phase. Moreover, the demand for external borrowing declines as cash flows yielded from internal operations are adequate to satisfy the operational requirements. Though mature firms can borrow at lower rates [42], they face a lack of future growth prospects owing to fewer profitable investment opportunities and a higher level of retained earnings [10]. Hence, any additional borrowing may yield negative returns because of limited positive NPV investment opportunities.

The fourth stage of corporate life cycle is the "revival phase" [3], "termination stage" [43], "renewal" [41], or "shake-out stage" [1]. As suggested by these names, researchers have competing arguments regarding the shake-out stage of a firm's life cycle. Miller and Friesen [3] and Lester and Parnell [41] propose that it is the most interesting stage of CLC. Considerable product innovations take place during this stage. Firm size increases and they expand exponentially. On the contrary, Dickinson and Gort and Klepper [1,44] contend that, during this stage, product lines start to decline and the decline in sales growth leads to declining prices [45]. However, the function of the shake-out stage of CLC is still vague in theory [1]. Thus, following [7,46,47], the shake-out stage is taken as the base in our regression analysis to compare the results of the rest of the CLC stages.

During the decline stage of CLC, firms usually abstain from innovation. They face higher bankruptcy risk [7] and their product lines become outdated and unattractive, which causes a substantial decrease in product price and revenues [3,45]. As a result, managers escalate investments to regain profitability. However, due to risk-averse and nondiversified behavior, they tend to invest in negative NPV undertakings to signal to shareholders that profitable investment options are still available [48]. However, hefty borrowing-driven investments in negative NPV projects may result in poor future performance, thus endangering their financial sustainability.

Thus, in light of the above discussion, we develop the following research hypotheses:

H1: Risk-taking at the introduction stage yields superior subsequent firm performance.

H2: Risk-taking at the growth stage yields superior current performance.

H3: Risk-taking at the mature and decline stages yields poor firm performance.

\section{Research Design}

\subsection{Selection and Measurement of Variables}

\subsubsection{Dependent Variable}

Firm performance is the dependent variable, which can be measured in several ways, such as sales growth, market capitalization, market to book ratio, turnover, and financial performance. The present study uses financial performance as the dependent variable to examine the proposed relationship. Return on Assets (ROA) and Return on Equity (ROE) are the two most commonly used proxies of corporate financial performance. ROA is measured as net income, scaled by total assets, whereas ROE is measured as net income scaled by stockholders' equity. The key difference between these two proxies is that a firm can increase its ROE, at least in the short run, by generous/higher utilization of debt without improving its earnings, though this is not the case with ROA. Moreover, in the present study bankruptcy risk is our main explanatory variable, which is also a function of a firm's debt level. Therefore, to get unbiased findings we employ ROA, measured as net earnings after tax divided by total assets, as our dependent variable. Furthermore, it is evident that when firms acquire capital assets or undertake heavy investments, their debt burden and consequent bankruptcy risk escalates in that particular period. However, this increased risk pays off in the subsequent years. Therefore, to assess 
the impact of current year bankruptcy risk on a firm's future performance, we also employ one year forward return on assets (ROA $t+1)$ as our second dependent variable.

\subsubsection{Explanatory Variables}

A firm's bankruptcy risk and its interaction between CLC stages (CLC stage*bankruptcy risk) are the main explanatory variables in this study. Careless selection of a bankruptcy risk measure can have adverse effects on the empirical outcome. Numerous studies have tried to measure the bankruptcy risk using a single firm-level variable such as book-to-market ratio, size, leverage, age, dividend payout, debt ratings, and group membership. These variables are not the true predictors of bankruptcy risk: for example, highly-leveraged firms have the highest bankruptcy risk, but this may not be true for a well-managed firm in a flourishing industrial segment. Similar views were presented by Clearly and Griffin and Lemmon $[49,50]$. Therefore, in the literature, a wide range of econometric models are available to gauge a firm's bankruptcy risk. Most of the models use different financial ratios to predict bankruptcy risk; for a good overview of these models, see, e.g., [51-54]. In the context of Pakistan, studies suggest that the Altman [51] model is an effective tool to measure the financial health of nonfinancial listed firms [55-58]. The Altman Z-score remains a familiar tool for evaluating the financial health of firms in recent research [7,59-61]. Therefore, we use Altman's Z-score as our primary dependent variable. Altman [51] used five explanatory variables and developed a model called the Altman Z-score. A lower Z-score (1.8 or below) indicates that a firm is at a high risk stage, while a higher $Z$-score ( 3 or above) predicts that a firm is in a stable situation. Thus, the inverse of the Altman Z-score is employed in the regression analysis.

Table 1 shows the year-wise bankruptcy risk level for sample firms on the basis of the Altman's Z-score. The data of financial ratios to calculate Z-score has been retrieved from a Balance Sheet Analysis (BSA) published by the State Bank of Pakistan (SBP). Calculations reveal that the highest number of firms was facing default risk in 2009. Moreover, in 2008 the number of at-risk firms was slightly less than in 2009. After 2009, the number of risky firms decreased steadily until 2013.

Table 1. Year-wise distribution of firms into various levels of bankruptcy risk using Altman's model.

\begin{tabular}{ccccc}
\hline Year & $\begin{array}{c}\text { Number of Firms with } \\
\text { No Bankruptcy Risk }\end{array}$ & Gray Area & $\begin{array}{c}\text { Number of Firms at High } \\
\text { Level of Bankruptcy Risk }\end{array}$ & $\begin{array}{c}\text { Percentage of } \\
\text { High-Risk Firms }\end{array}$ \\
\hline 2005 & 66 & 45 & 123 & 52.6 \\
\hline 2006 & 68 & 51 & 121 & 50.4 \\
\hline 2007 & 72 & 56 & 175 & 52.4 \\
\hline 2008 & 65 & 46 & 197 & 61.2 \\
\hline 2009 & 51 & 47 & 168 & 66.8 \\
\hline 2010 & 67 & 65 & 164 & 56.0 \\
\hline 2011 & 69 & 63 & 170 & 55.4 \\
\hline 2012 & 59 & 64 & 138 & 58.0 \\
\hline 2013 & 73 & 80 &
\end{tabular}

Moreover, it is difficult to calculate the life cycle stage of a particular firm that is offering fairly diverse products in multiple industries [1]. Keeping this in mind, we follow the approach used by Dickinson [1] to calculate the corporate life cycle stages. She posited that a firm's cash flow is a gauge of variations in its profitability, growth, and risk. Thus, we can classify firms into various stages of corporate life cycle, such as introduction, growth, maturity, shake-out, and decline through operating cash flows (OCF), investing cash flows (ICF), and financing cash flows (FCF). The methodology to segregate the firms is elaborated below:

Introduction, if OCF is (-), ICF is (-) while FCF is (+); 
Growth, if OCF is (+), ICF is (-) while FCF is $(+)$;

Mature, if OCF is $(+)$, ICF is $(-)$ while FCF is $(-)$;

Decline, if OCF is $(-)$, ICF is $(+)$ while FCF is $(+/-)$;

Shake-out $=$ any pattern other than the aforementioned categories,

where + indicates cash flows with a value that is $>0$, while - shows cash flows with a value $<0$.

Figure 1 is a pie diagram that shows the life cycle-wise distribution of sample firms based on Dickinson's [1] model. Cash flow data to calculate corporate life cycle stages are retrieved from the OSIRIS database. They show that $43 \%$ of the sample firms are mature, while $7 \%$ are experiencing the decline stage of the corporate life cycle. Likewise, introduction, growth, and shake-out firms have shares of $18 \%, 18 \%$, and $14 \%$, respectively.

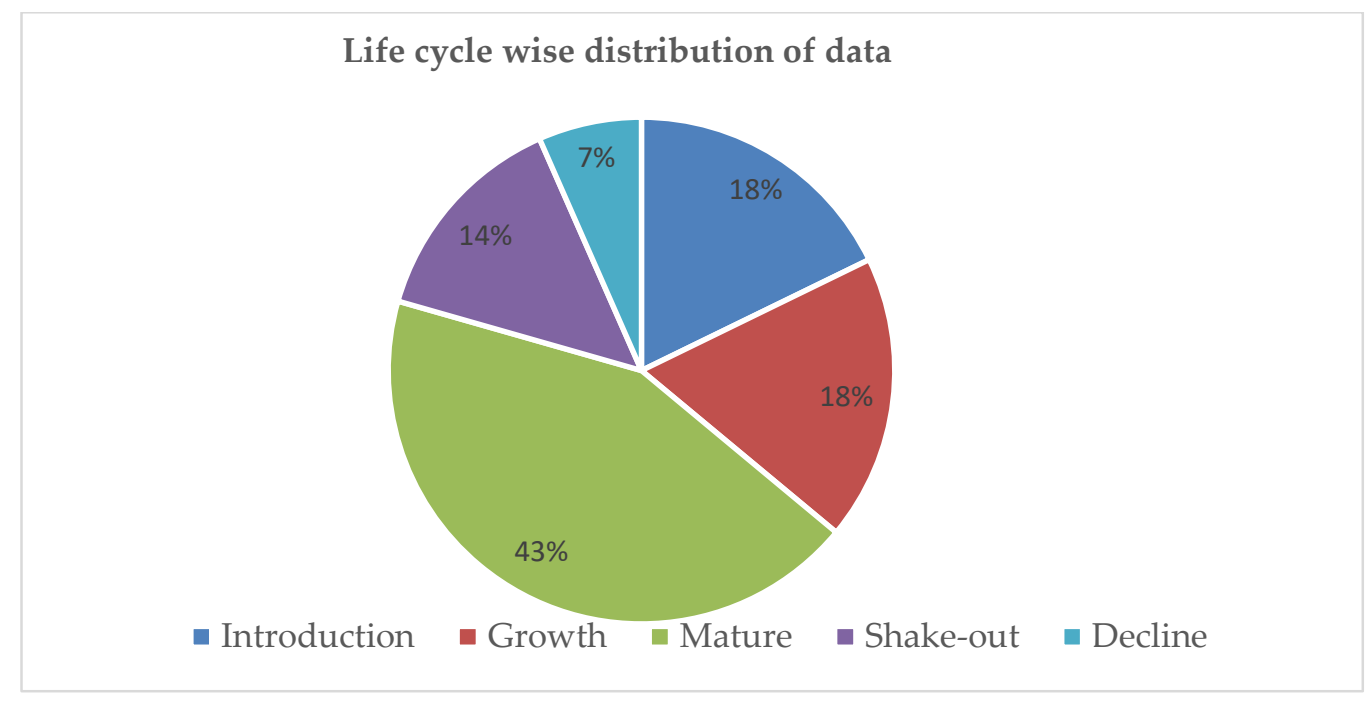

Figure 1. Life cycle-wise distribution of sample firms using Dickinson's model.

\subsubsection{Firm-Level Control Variables}

Firm performance is influenced by several internal factors (e.g., firm size, growth, leverage, and capital expenditure). Hence, the present study incorporates several firm-level controls that may be associated with firm profitability, as omission of these controls can give rise to unobserved heterogeneity and the correlated omitted variable issue. Comprehensive variable descriptions are presented in Appendix A.

\subsubsection{Industry-Level Control Variables}

We also employ control for the industry competition (INDCOM). Industry competition is calculated by using the Herfindahl index. It is a measure of firm size relative to the industry and also an indicator of the intensity of competition between firms. The Herfindahl index is calculated as the sum of the squares of the market share of firms within an industry. In such a way, the measure of industry competition will range between 0 and 10,000; a larger Herfindahl index suggests highly concentrated industry with lower competition. Following is the criteria declared by the Federal Trade Commission of America to classify an industry in any market structure using the Herfindahl index (HHI):

i. If the $\mathrm{HHI}$ value is less than 1000, the industry will be considered unsaturated (competitive market);

ii. An HHI value ranging between 1000 and 1800 means the industry is moderately saturated (monopolistic competition);

iii. If the HHI value is more than 1800, it is a saturated market (oligopoly; if the value is $>10,000$ then it is a pure monopoly). 
Table 2 shows the level of concentration/competition in our sample firms within their industry using HHI scores. Stock prices data to calculate HHI for 2005 to 2013 were obtained from the business recorder group website khistocks.com. HHI scores reveal that the textile sector is the only sector that remained perfectly competitive during the study period. Chemicals, chemical products, and pharmaceuticals and motor vehicles, trailers, and auto parts were moderately saturated industries. Meanwhile, the food industry was a perfectly competitive market for 2005 to 2011. Afterwards, it was categorized as a moderately concentrated industry-except in 2012, when the HHI score reached the 1969 level. Likewise, the fuel and energy sector was found to be a moderately concentrated sector for the observed time period. The rest of the five industries were operating in an oligopolistic competition environment, except for other manufacturing, which remained concentrated during 2005 to 2007; in the subsequent period, it became a moderately concentrated industry-excluding 2011, when the HHI score was 992 (yearly scores are not reported in the table to conserve space).

Table 2. Industry wise competition/concentration using the Herfindahl index.

\begin{tabular}{|c|c|c|c|}
\hline Industry & HHI Scores Range & Concentration & Market Structure \\
\hline Textile & 222 to 280 & Unconcentrated & Perfect competition \\
\hline $\begin{array}{c}\text { Chemicals, Chemical } \\
\text { Products, } \\
\text { and Pharmaceuticals }\end{array}$ & 1003 to 1310 & Moderately concentrated & Monopolistic competition \\
\hline $\begin{array}{l}\text { Other Nonmetallic } \\
\text { Mineral } \\
\text { Products-Overall }\end{array}$ & 654 to 1191 & $\begin{array}{l}\text { Unconcentrated + Moderately } \\
\text { concentrated }\end{array}$ & $\begin{array}{l}\text { Perfect competition }+ \\
\text { Monopolistic competition }\end{array}$ \\
\hline $\begin{array}{l}\text { Other Manufacturing } \\
\text { n.e.s. }\end{array}$ & 992 to 1988 & $\begin{array}{l}\text { Unconcentrated + Moderately } \\
\text { concentrated + concentrated }\end{array}$ & $\begin{array}{l}\text { Perfect competition+ } \\
\text { Monopolistic competition+ } \\
\text { Oligopolistic competition }\end{array}$ \\
\hline $\begin{array}{l}\text { Motor Vehicles, Trailers, } \\
\text { and Auto parts }\end{array}$ & 1243 to 1677 & Moderately concentrated & Monopolistic competition \\
\hline Food & 802 to 1969 & $\begin{array}{l}\text { Un-concentrated + Moderately } \\
\text { concentrated + concentrated }\end{array}$ & $\begin{array}{l}\text { Perfect competition+ } \\
\text { Monopolistic competition+ } \\
\text { Oligopolistic competition }\end{array}$ \\
\hline Fuel and Energy & 1453 to 1860 & $\begin{array}{l}\text { Moderately concentrated }+ \\
\text { concentrated }\end{array}$ & $\begin{array}{l}\text { Monopolistic competition+ } \\
\text { Oligopolistic competition }\end{array}$ \\
\hline $\begin{array}{l}\text { Information, Comm., } \\
\text { and Transport Services }\end{array}$ & 3879 to 4317 & Concentrated & Oligopolistic competition \\
\hline $\begin{array}{l}\text { Coke and Refined } \\
\text { Petroleum Products }\end{array}$ & 2523 to 3472 & Concentrated & Oligopolistic competition \\
\hline $\begin{array}{l}\text { Paper, Paperboard, } \\
\text { and Products }\end{array}$ & 3206 to 4334 & Concentrated & Oligopolistic competition \\
\hline Other Service Activities & 3242 to 5674 & Concentrated & Oligopolistic competition \\
\hline $\begin{array}{l}\text { Electrical Machinery and } \\
\text { Apparatus }\end{array}$ & 3197 to 6488 & Concentrated & Oligopolistic competition \\
\hline
\end{tabular}

Source: Authors' calculation.

\subsubsection{Country-Level Controls}

The study employed country-level economic controls in the regression analysis as these are suggested in the extant literature to have an impact on firm performance. Economic controls, industrial growth (INDGR), and GDP growth (GGDP) are included in the analysis to avoid the unobserved heterogeneity.

\subsection{Sample and Data Collection}

The research sample consists of all the nonfinancial listed firms in Pakistan from 2005 to 2013. The final sample includes only those firms with five consecutive years of published data available. This practice results in 295 firms with 2464 firm-year observations in 12 diverse industries. Cash flow 
data to calculate corporate life cycle stage were retrieved from the OSIRIS database. Stock price data were obtained from the business recorder group's website khistocks.com. To calculate bankruptcy risk proxy and control variables, the Balance Sheet Analysis (BSA) published by the State Bank of Pakistan (SBP) has been used. GDP growth data are retrieved from the World Development Index (WDI) of the World Bank. Finally, industrial growth data were obtained from the Central Intelligence Agency (CIA) World Factbook. Additionally, annual reports of the respective firm were also consulted to make up for the missing observations.

\subsection{Empirical Strategy}

The structure of our dataset is hierarchical in nature, consisting of 295 firms nested in 12 industries of Pakistan. From the econometric standpoint, firm-level observations are grouped under higher units (e.g., industries and countries); therefore, data analysis through OLS regressions can give rise to issues like biased estimates of standard errors or correlated error terms, and thus lead to biased interpretation of the results [62]. Moreover, it is essential to differentiate the firm-level effects from the industry- or country-level effects in order to understand the role of firm- versus industry- and country-level variables and to suitably model their interaction. Hence, the present study adopts hierarchical linear mixed models (HLMM) regression estimates, which can process multilevel data when observations are not completely independent; see [63] or [64] for an introduction to HLMM. In the present study, firms within a given industry form the base-level observations, while industries serve as higher-level observations.

There are several benefits to using a multilevel hierarchical model. First, we can test multilevel observations by simultaneously categorizing the variables at lower (firm) and higher (industry) levels without segregating the data. Second, the HLMM estimation can handle unbalanced panel data in cases where the sample size varies significantly across industries. In our study, the number of firms varies considerably across 12 diverse industrial segments. Thus, HLMM is a more suitable econometric approach for this study.

\subsection{Alternate Methodology}

The advantage of using panel-based models is that they help to control unobserved heterogeneity, which minimizes the possibility of getting biased results due to heterogeneity [65]. Therefore, we also apply panel fixed-effects and random-effects regressions as a robustness check. A Hausman post-estimation test was performed to choose the preferred model between fixed-effects and random-effects regressions.

\subsection{Empirical Model}

The following regression models were employed to empirically examine the hypotheses raised in this paper. The first model expresses the association between a firm's bankruptcy risk and current performance. The second model examines the linkage between bankruptcy risk and future corporate performance. ROA and $\mathrm{ROA}_{\mathrm{T}+1}$ are the dependent variables for Equations (1) and (2), respectively. Our main variable of interest is Risk * FLCS, which is a vector of the dummy variables that symbolize corporate bankruptcy risk's interaction with firm life cycle stages, whereas $\beta 2, \beta 3, \beta 4$, and $\beta 5$ denote bankruptcy risk * introduction, bankruptcy risk * growth, bankruptcy risk * mature, and bankruptcy risk*decline, respectively. SIZE, MTB, FAGR, INDCOM, INDGR, and GGDP are control variables and represent firm size, market to book ratio, growth in fixed assets, industry competition, industrial growth, and GDP growth of the country, respectively. For variables' description and calculation, see Appendix A.

$$
\begin{gathered}
R O A_{i, t}=\alpha_{\mathrm{O}}+\beta_{1} \text { Risk }_{i, t} \sum_{k=2}^{5} \beta_{k} \text { Risk }_{i, t} * \text { FLCS }_{k, i, t}+\beta_{6} \operatorname{SIZE}_{i, t}+\beta_{7} \mathrm{MTB}_{i, t} \\
+\beta_{8} F A G R_{i, t}+\beta_{9} I N D C O M_{i, t}+\beta_{10} I N D G R_{i, t}+\beta_{11} G G D P_{i, t}+\varepsilon_{i, t}
\end{gathered}
$$




$$
\begin{gathered}
R O A_{i, t+1}=\alpha_{\mathrm{O}}+\beta_{1} \text { Risk }_{i, t} \sum_{k=2}^{5} \beta_{k} \text { Risk }_{i, t} * \mathrm{FLCS}_{k, i, t}+\beta_{6} \operatorname{SIZE}_{i, t}+\beta_{7} M T B_{i, t} \\
+\beta_{8} F A G R_{i, t}+\beta_{9} I N D C O M_{i, t}+\beta_{10} I N D G R_{i, t}+\beta_{11} G G D P_{i, t}+\varepsilon_{i, t}
\end{gathered}
$$

\section{Results and Discussion}

\subsection{Descriptive Analysis}

Table 3 presents the descriptive statistics of variables. The average values of ROA, a profitability measure, shows that sample firms generate negative profits at the introduction $(-0.080)$ and decline $(-1.73)$ stages, while profitability is at its peak during the mature (9.41) stage of corporate life cycle. Moreover, the bankruptcy risk measure for the introduction $(-1.32)$, growth $(-1.78)$, and decline $(-0.929)$ stages is higher than for the mature $(-2.76)$ stage. FSIZE shows that firms are smaller in size at the introduction stage (12.8) and grow significantly during the growth (13.5) and mature (13.63) stages. However, they start to shrink again at the decline (12.13) stage. In line with corporate life cycle proposition, the MTB increases when the firm progresses from the introduction $(0.217)$ to the mature (1.29) stages and declines as firms transition from the mature to the decline stage (0.839). Furthermore, fixed assets grow between the introduction and growth stages but diminish during the mature and decline stages.

Table 3. Descriptive statistics.

\begin{tabular}{cccccccccc}
\hline Variables & $\boldsymbol{N}$ & Mean & S.D. & 5th percent & 95th percent & Intro & Grow & Mature & Decline \\
\hline ROA & 2662 & 5.67 & 14.2 & -13.43 & 30.66 & -0.080 & 5.52 & 9.41 & -1.73 \\
\hline ROA $_{+1}$ & 2662 & 5.42 & 14.2 & -13.71 & 29.81 & -0.525 & 4.44 & 8.98 & 1.02 \\
\hline RISK & 2789 & -2.16 & 2.99 & -6.48 & 0.560 & -1.32 & -1.78 & -2.76 & -0.992 \\
\hline SIZE & 2789 & 13.30 & 2.26 & 9.85 & 17.20 & 12.80 & 13.50 & 13.63 & 12.13 \\
\hline MTB & 2789 & 0.958 & 10.80 & -0.122 & 3.65 & 0.217 & 0.847 & 1.29 & 0.819 \\
\hline FAG & 2789 & 0.293 & 2.17 & -0.110 & 1.03 & 0.257 & 0.423 & 0.201 & 0.234 \\
\hline INCOM & 2789 & 1179 & 1157 & 232 & 3983 & 983 & 1171 & 1207 & 1134 \\
\hline INDGR & 2789 & 4.49 & 3.25 & -1.90 & 10.70 & 4.76 & 5.09 & 4.21 & 3.76 \\
\hline GGDP & 2789 & 3.79 & 1.87 & 1.60 & 7.70 & 3.74 & 4.33 & 3.70 & 3.25 \\
\hline
\end{tabular}

Statistics on industry competition/concentration suggest that firms at the introduction stage are less concentrated $(\mathrm{HHI}=983)$ and face a high level of competition. However, when firms advance from the introduction to the mature stage, they get much more concentrated and face less competition at the successive stages of their life cycle.

The mean values of INDGR and GGDP are 4.49 and 3.87 respectively. Life cycle-wise statistics indicate that when the values of industrial 5.09 and GDP 4.33 growth were higher, firms were at the growth stage. Contrarily, during the period of low industrial 3.76 and GDP 3.25 growth, firms switched to the decline stage.

Figure 2 depicts variations in firm bankruptcy risk and financial performance at different stages of the corporate life cycle. Whereas Return on Assets (ROA) and one-year-ahead Return on Assets $(\mathrm{ROA}+1)$ is used to measure corporate financial performance, the Altman z-score is deployed as a bankruptcy risk measure. It is evident that firms engaged in higher risk at the introduction stage, which gradually decreased and reached at a minimum level during the mature stage of the life cycle. However, consistent with the expectations, when firms transition from the mature to the decline stage, their bankruptcy risk tends to escalate rapidly. Interestingly, firm performance is inversely proportionate to its bankruptcy risk. Financial performance improves when firms move from the introduction to the mature stage and begins to deteriorate from the mature to the decline stage. The evidence strongly supports the notion that not only does the financial sustainability of firms vary 
across the corporate life cycle, but also their associated financial performance is influenced differently at each stage of CLC.

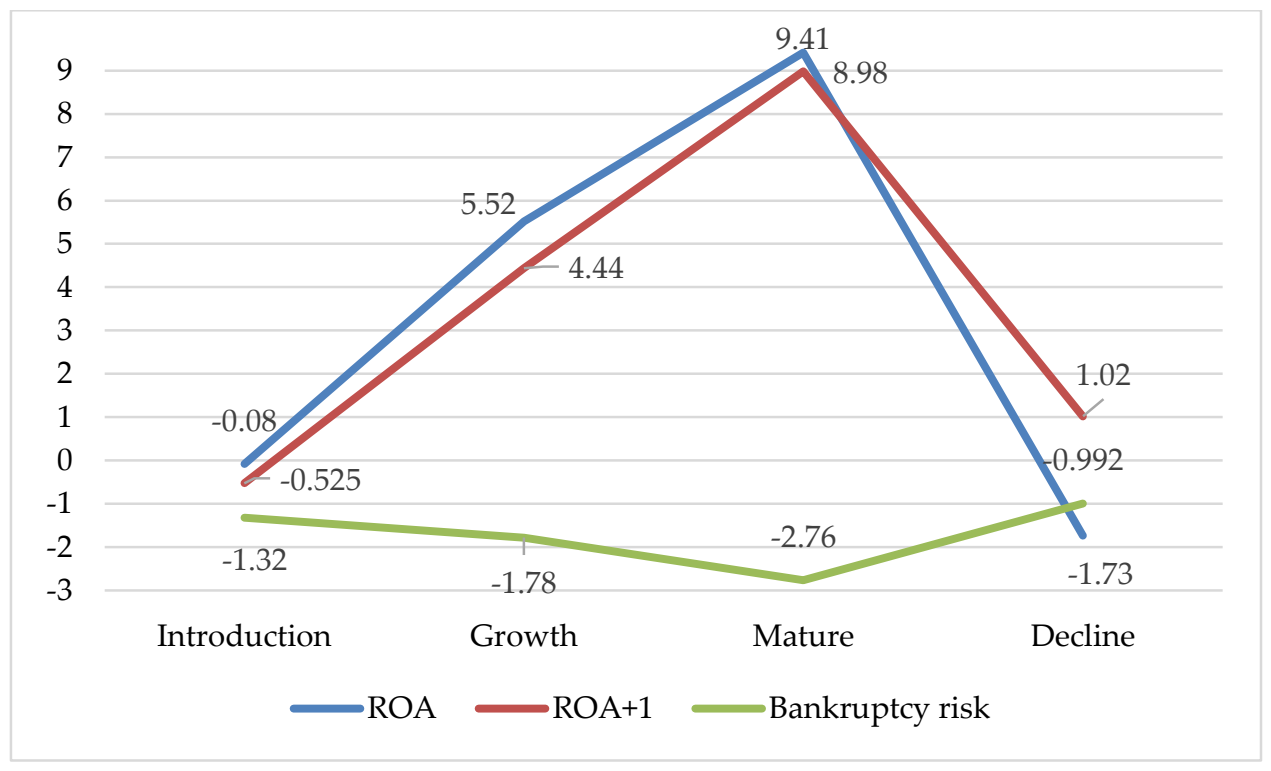

Figure 2. Life cycle-wise bankruptcy risk and return of sampled firms.

Table 4 shows the results of a pairwise correlation analysis of the baseline variables. The performance proxy ROA has a negative correlation with bankruptcy risk and fixed assets growth, but a positive association with FSIZE, MTB, INCOM, INGR, and GDPG. Firm size has a significant positive coefficient with market to book ratio, referring to the findings of Table 1 , which suggests that firms at the introduction phase are smaller in size (12.8); however, their size increases as they pass through the growth (13.5) stage and is largest during the mature stage (13.63) of the life cycle. This correlation shows that, during the introduction phase of the life cycle, firms have limited information available to investors, which leads to a higher risk being associated with their stocks. However, as firms pass through different stages of the life cycle, they have more information available for stakeholders. Therefore, as compared to infant firms, investors tend to attribute more value to the stocks of growing and mature firms. Furthermore, growth in fixed assets is negatively associated with ROA, while this relationship is positive for $\mathrm{ROA}_{+}$. It reflects that investment in fixed assets yields profitability in the future.

Overall, in some cases the correlation among control variables is significant, which may give rise to a multicollinearity issue in the proposed models. Therefore, we applied Variance Inflation Factor (VIF) analysis to check if such a problem exists in our data. A VIF value of 10 or higher shows that variables have multicollinearity [66]. However, none of our variables have a VIF value greater than the prescribed limit, thus eradicating the possibility of multicollinearity in our analysis (see Appendix B). 
Table 4. Correlation analysis.

\begin{tabular}{|c|c|c|c|c|c|c|c|c|c|}
\hline & ROA & $\mathrm{ROA}_{1}$ & RISK & SIZE & МТВ & FAG & INCOM & INGR & GDPG \\
\hline ROA & 1.000 & & & & & & & & \\
\hline $\mathrm{ROA}_{1}$ & $0.598^{*}$ & 1.000 & & & & & & & \\
\hline RISK & $-0.579^{*}$ & $-0.413^{*}$ & 1.000 & & & & & & \\
\hline SIZE & $0.396^{*}$ & $0.325^{*}$ & $-0.37^{*}$ & 1.000 & & & & & \\
\hline MTB & 0.016 & 0.012 & $0.111^{*}$ & $0.086^{*}$ & 1.000 & & & & \\
\hline FAG & -0.004 & 0.013 & -0.019 & 0.0339 & 0.003 & 1.000 & & & \\
\hline INCOM & $0.143^{*}$ & $0.115^{*}$ & $-0.12^{*}$ & $0.338^{*}$ & $0.082^{*}$ & 0.019 & 1.000 & & \\
\hline INGR & $0.100^{*}$ & 0.034 & $-0.09^{*}$ & $0.077^{*}$ & -0.004 & -0.033 & 0.015 & 1.000 & \\
\hline GGDP & $0.099^{*}$ & $0.0789^{*}$ & $-0.09^{*}$ & $0.089^{*}$ & -0.013 & 0.025 & 0.0188 & $0.626^{*}$ & 1.0000 \\
\hline
\end{tabular}

\subsection{Regression Analysis}

Table 5 reports the results of our baseline analysis, using HLMM regression to examine the association between corporate performance and bankruptcy risk at various stages of the life cycle. Robust $t$-statistics are in parentheses, while ${ }^{* * * * *}$, and ${ }^{*}$ indicate $1 \%, 5 \%$, and $10 \%$ significance levels, respectively. We estimate two regression models with current ROA and one-year-ahead ROA as the dependent variables. Key variables of interest in both regression models are the interaction between corporate bankruptcy risk and life cycle stages (Risk ${ }^{*}$ CLC stages), and firms' current (ROA) and future performance $\left(\mathrm{ROA}_{+1}\right)$.

The findings of Model 1 reveal that, irrespective of firm life cycle stages, ROA has a negative relationship with bankruptcy risk, inferring that escalated risk levels lead to a decline in corporate profitability. Similar findings were reported by $[22,23]$ using different proxies of risk. RISK*Intro shows a positive yet insignificant correlation with ROA, which could be attributed to the fact that introductory firms focus on breakthrough innovations that can unleash their productivity potential and performance in the succeeding years. Likewise, RISK ${ }^{*}$ Grow has a significantly $(p<0.05)$ positive association with ROA, having a coefficient of 0.479 . This shows that growing firms borrow heavily through external funding sources [7]; however, high revenue growth and an emphasis on product innovation with a growing market share help to improve the firm's profitability. In line with H3, RISK*Mature has a significantly negative relationship with ROA. This suggests that, during the introduction stage, firms have more possibilities to invest in profitable avenues. Their product and process innovation will also be more attractive for customers; therefore, by assuming more risk, such firms can gain higher profitability. However, mature firms have very limited profitable investment avenues; therefore, managers may invest in negative NPV projects to give positive signals to stakeholders. Nevertheless, their innovation level also declines with stagnating sales [1,3]. Therefore, risk-taking at the mature stage generates negative future profitability. Consistent with the prospect theory, RISK*Decline has a negative and statistically significant relationship with performance, suggesting that managers of decline firms undertake hefty investments in a turnaround effort yet a risk-averse attitude may lead to investing in bad gambles, which generates poor returns. 
Table 5. Panel A1: Baseline HLMM regressions of bankruptcy risk and firm performance at different life cycle stages.

\begin{tabular}{|c|c|c|c|c|}
\hline & \multirow{2}{*}{ Expected Sign } & Model 1 & \multirow{2}{*}{ Expected Sign } & Model 2 \\
\hline & & ROA & & $\mathrm{ROA}+1$ \\
\hline \multirow[t]{2}{*}{ RISK } & \multirow{2}{*}{-} & $-2.182^{* * *}$ & \multirow{2}{*}{$+?$} & $-0.893^{* * *}$ \\
\hline & & $(-14.45)$ & & $(-5.22)$ \\
\hline \multirow[t]{2}{*}{ RISK*Intro } & \multirow{2}{*}{+} & 0.185 & \multirow{2}{*}{+} & $0.640^{* *}$ \\
\hline & & $(0.74)$ & & $(2.21)$ \\
\hline \multirow[t]{2}{*}{ RISK*Grow } & \multirow{2}{*}{+} & $0.478^{* *}$ & \multirow{2}{*}{+} & 0.287 \\
\hline & & $(2.43)$ & & $(1.26)$ \\
\hline \multirow[t]{2}{*}{ RISK*Mature } & \multirow{2}{*}{-} & $-0.865^{* * *}$ & \multirow{2}{*}{-} & $-0.892^{* * *}$ \\
\hline & & $(-5.63)$ & & $(-5.03)$ \\
\hline \multirow[t]{2}{*}{ RISK*Decline } & \multirow[t]{2}{*}{-} & $-1.021^{* * *}$ & \multirow[t]{2}{*}{-} & -0.439 \\
\hline & & $(-3.08)$ & & $(-1.14)$ \\
\hline \multirow[t]{2}{*}{ SIZE } & \multirow{2}{*}{+} & $1.257^{* * *}$ & \multirow{2}{*}{+} & $0.861^{* * *}$ \\
\hline & & (7.08) & & $(4.48)$ \\
\hline \multirow[t]{2}{*}{ МTB } & \multirow{2}{*}{+} & $0.0602^{* * *}$ & \multirow{2}{*}{+} & -0.0206 \\
\hline & & $(2.81)$ & & $(-0.83)$ \\
\hline \multirow[t]{2}{*}{ FAG } & \multirow{2}{*}{-} & 0.129 & \multirow{2}{*}{+} & 0.106 \\
\hline & & $(1.43)$ & & $(1.01)$ \\
\hline \multirow[t]{2}{*}{ INCOM } & \multirow{2}{*}{+} & -0.000110 & \multirow{2}{*}{+} & 0.000233 \\
\hline & & $(-0.32)$ & & $(0.63)$ \\
\hline \multirow[t]{2}{*}{ INGR } & \multirow{2}{*}{+} & 0.0805 & \multirow{2}{*}{$+?$} & $-0.204^{* *}$ \\
\hline & & (1.11) & & $(-2.40)$ \\
\hline \multirow[t]{2}{*}{ GGDP } & \multirow{2}{*}{+} & 0.123 & + & $0.499^{* * *}$ \\
\hline & & $(0.97)$ & & $(3.34)$ \\
\hline Constant & & $-17.69^{* * *}$ & & $-10.30^{* * *}$ \\
\hline$N$ & & 2464 & & 2464 \\
\hline
\end{tabular}

Interestingly, the regression results of Model 2 reveal that overall bankruptcy risk has a significant negative coefficient with firms' future performance. However, the coefficients show that the average impact of bankruptcy risk is much higher on current performance as compared to the future performance of firms. This implies that firms borrow heavily to buy capital assets, which reduces their current earnings; however, as those assets start contributing to the income/value of the firm, corporate profitability increases, which helps to improve firm performance in subsequent years. Unlike in Model 1 , risk-taking at the introduction stage has a significantly $(p<0.05)$ positive association with $\mathrm{ROA}_{t+1}$. It strengthens the proposition that introduction firms take time to establish their business and start to generate profits. In addition, introduction firms engage in major innovation projects with a long-term strategic orientation, so risk-taking at this stage generates positive outcomes. RISK ${ }^{*}$ Grow is also positively associated with future performance-though, unlike with Model 1, this association is not significant. This shows that the performance of growth firms does not respond to past risk propensities; instead, it is associated with their current level of bankruptcy risk. Similar to Model 1, RISK*Mature 
has a significantly $(p<0.01)$ negative association with future performance. Likewise, bankruptcy risk at the decline stage has a negative yet insignificant association with future ROA.

As with the control variables, the reported results belong to Model 1. FSIZE indicates a positive and significant relationship with firm performance, meaning that large firms intend to generate better performance. As expected, a firm's market to book ratio and sales growth contribute to its performance. Growth in fixed assets has an insignificant correlation with firm performance. This reveals that investment in fixed assets such as land and machinery is a part of long-term planning that will contribute to firm performance in the long run. Industry competition has no significant association with firm-level performance. Among country-level variables, industrial growth rates reveal a negative and significant link with future performance, while GDP growth is positively associated with a firm's future performance.

Table 6 presents the random part of our HLMM model. In this table, the observation's residual is partitioned into three parts that define its value in relation to the firm, industry, and grand means. Statistics reveal that the observations diverge from their firm mean by an average of 9.06, with a standard error of 0.144 , and firm mean deviates from the respective industry mean by an average of 6.39. The industry mean of sample observations deviates from the grand mean by 0.00002 . In short, this evidence strengthens our belief that the model specification is reasonable.

Table 6. (Panel-A2) Random part of this HLMM model.

\begin{tabular}{ccc}
\hline Random-Effects Parameters & Standard Deviation & Standard Error \\
\hline Industry & 0.00002 & 0.00013 \\
\hline Firm & 6.39 & 0.345 \\
\hline Residual & 9.060 & 0.144 \\
\hline
\end{tabular}

To check the robustness, in Table 7 we examine the similar regression models using the panel fixed effects regression estimation. Bankruptcy risk indicates a significant $(0.01)$ and negative association with current and future firm performance. Consistent with the findings of HLMM, the coefficient for future performance is much lower than that of the current performance.

RISK*Intro is positively associated with ROA and ROA $t+1$. Similarly, bankruptcy risk has a positive correlation with the performance of the growth firms; however, this association is significant only for the current performance. RISK*Mature shows a negative and statistically significant coefficient with current and future performance $(p<0.01)$. Similarly, risk-taking at the decline stage also reveals a negative coefficient. Among control variables, sales growth, market to book ratio, firm size, and growth in fixed assets have positive and statistically significant associations with corporate performance. Summing up, the findings of Table 7 are highly aligned with the findings of Table 5, which indicates that our results are robust. 
Table 7. Robustness check-bankruptcy risk and corporate performance at different CLC stages using the fixed-effects model.

\begin{tabular}{|c|c|c|c|c|}
\hline & \multirow{2}{*}{ Expected Sign } & (Fixed-Effects) & \multirow{2}{*}{ Expected Sign } & (Fixed-Effects) \\
\hline & & ROA & & $\mathrm{ROA}+1$ \\
\hline \multirow[t]{2}{*}{ RISK } & \multirow{2}{*}{-} & $-2.739^{* * *}$ & \multirow{2}{*}{$+?$} & $-0.846^{* * *}$ \\
\hline & & $(-15.14)$ & & $(-4.01)$ \\
\hline \multirow[t]{2}{*}{ RISK*Intro } & \multirow{2}{*}{+} & $0.567^{* *}$ & \multirow{2}{*}{+} & $0.620^{* *}$ \\
\hline & & $(2.15)$ & & $(2.01)$ \\
\hline \multirow[t]{2}{*}{ RISK*Grow } & \multirow{2}{*}{+} & $1.056^{* * *}$ & \multirow{2}{*}{+} & 0.411 \\
\hline & & $(4.90)$ & & (1.63) \\
\hline \multirow[t]{2}{*}{ RISK*Mature } & \multirow{2}{*}{-} & $-0.436^{* * *}$ & \multirow{2}{*}{-} & $-0.527^{* * *}$ \\
\hline & & $(-2.64)$ & & $(-2.73)$ \\
\hline \multirow[t]{2}{*}{ RISK*Decline } & \multirow[t]{2}{*}{-} & $-0.786^{* *}$ & \multirow[t]{2}{*}{-} & -0.225 \\
\hline & & $(-2.30)$ & & $(-0.57)$ \\
\hline \multirow[t]{2}{*}{ SIZE } & \multirow{2}{*}{+} & $1.701^{* * *}$ & \multirow{2}{*}{+} & $-0.873^{* *}$ \\
\hline & & $(5.25)$ & & $(-2.31)$ \\
\hline \multirow[t]{2}{*}{ MTB } & \multirow{2}{*}{+} & $0.0737^{* * *}$ & \multirow{2}{*}{+} & -0.0226 \\
\hline & & (3.37) & & $(-0.89)$ \\
\hline \multirow[t]{2}{*}{ FAG } & \multirow{2}{*}{-} & $0.295^{* * *}$ & \multirow{2}{*}{+} & 0.145 \\
\hline & & (3.13) & & $(1.32)$ \\
\hline \multirow[t]{2}{*}{ INCOM } & \multirow{2}{*}{+} & -0.000656 & \multirow{2}{*}{+} & -0.000320 \\
\hline & & $(-0.84)$ & & $(-0.35)$ \\
\hline \multirow[t]{2}{*}{ INGR } & \multirow{2}{*}{+} & 0.0539 & \multirow{2}{*}{+} & $-0.153^{*}$ \\
\hline & & $(0.74)$ & & $(-1.79)$ \\
\hline \multirow[t]{2}{*}{ GGDP } & + & 0.0825 & + & $0.555^{* * *}$ \\
\hline & & $(0.65)$ & & $(3.72)$ \\
\hline Constant & & $-22.97^{* * *}$ & & $13.79^{* *}$ \\
\hline & & $(-5.37)$ & & $(2.76)$ \\
\hline $\mathrm{N}$ & & 2464 & & 2464 \\
\hline
\end{tabular}

\section{Conclusions}

Risk is a fundamental factor affecting the financial health and smooth functioning of an enterprise. The financial crisis of 2008 and the liquidity crunch that followed have forced managers and researchers to evaluate the implications of corporate risk-taking on sustainable financial performance. This study investigates the association between a firm's bankruptcy risk and its current and future performance at various stages of the corporate life cycle. Following the entrepreneurial activity approach and prospect theory, we suppose that, at the early stages of their life cycle, firms have considerable opportunities to grow by investing in positive NPV projects; however, as firms mature, further investment in existing projects tends to cause a decline in profitability due to a nondiversified and self-serving approach, as managers may avoid investing in risky NPV undertakings. Hence, bankruptcy risk at the introduction and growth stages is positively associated with a firm's financial performance and negatively linked with the performance of mature and decline firms. 
Empirical evidence suggests that, irrespective of the life cycle stages, bankruptcy risk results in negative current and future profitability. Moreover, the performance of introduction and growth firms responds positively to risk-taking. Contrarily, risk-taking during the mature and decline stages negatively correlates with firm performance, giving an inverted-U shaped pattern. This research unveils some noteworthy findings, as introduction firms have a positive but insignificant association with current performance; however, this relationship is significant for future performance, indicating that, during the start-up stage, firms mainly focus on breakthrough innovations and product development processes. Once this innovation activity is successful, it is likely to yield profitable outcomes in subsequent years. Similarly, risk-taking at the growth stage is significantly associated with current performance but insignificantly associated with the next year's performance. This indicates that the performance of these firms is quite responsive to their current capital inflows.

This study makes some important contributions to the corporate sustainability domain. First, it contributes to the enterprise management literature by directly examining the impact of firm life cycle stages on the relationship between bankruptcy risk and firm performance. Prior studies have ignored the perceived impact of life cycle stages in determining the risk-return relationship. Moreover, most earlier studies such as [20,22] report conflicting empirical findings. Second, the results of the present research suggest that managerial decisions of mature and decline firms are not aligned with the wealth maximization objective of shareholders and excessive risk-taking at these stages can considerably endanger a firm's financial sustainability. The study has practical implications for various corporate stakeholders. Managers should adjust the bankruptcy risk of their firms to be in line with the respective life cycle stage to avoid a bank run. Likewise, investors should be more cautious when investing in mature and declining firms. Furthermore, a firm's shareholders should also exert pressure on the management to align their financial decisions with the respective CLC stage to ensure the sustainable functioning of their business in crisis situations.

However, the study also has some limitations that are worth mentioning. First, the research sample is confined to listed Pakistani firms. Hence, the findings of this study can only be generalized to listed firms in developing countries with similar macroeconomic dynamics. Further studies in this area can explore how this relationship prevails in the context of advanced economies. Second, our research only takes into account the bankruptcy form of risk, ignoring other risk categories such as country risk, political risk, market risk, operational risk, etc. Therefore, future studies in this domain can explore the influence of CLC stages on the association between other risk categories and the financial performance of an enterprise.

Author Contributions: Conceptualization, M.A.; methodology, M.A.; formal analysis, M.A.; writing-original draft preparation, A.A.; writing-review and editing, P.M., H.M.A., and M.Y.; funding acquisition, P.M. All authors have read and agreed to the published version of the manuscript.

Funding: This research was funded by the Excellence project (2020) of the Faculty of Informatics and Management, University of Hradec Kralove, Czech Republic.

Acknowledgments: The authors thank the anonymous reviewers for their useful comments on the earlier version of this article. We also acknowledge the financial support by the University of Hradec Kralove to support the open access of this article.

Conflicts of Interest: The authors declare no conflict of interest. 


\section{Appendix A}

Table A1. Variables' definition and measurement.

\begin{tabular}{|c|c|c|c|}
\hline $\begin{array}{l}\text { Variable Category and } \\
\text { Name }\end{array}$ & Description & Calculation & Expected Sign \\
\hline \multicolumn{4}{|c|}{ Dependent Variables } \\
\hline Return on assets & ROA & $\begin{array}{l}\text { Net income before tax, scaled by } \\
\text { total assets at the end of fiscal year }\end{array}$ & $\begin{array}{l}\text { Future performance is expected to } \\
\text { have a negative association with the } \\
\text { bankruptcy risk-taking of a firm }\end{array}$ \\
\hline Future return on assets & $\mathrm{ROA}_{\mathrm{t}+1}$ & One-year-ahead return on assets & $\begin{array}{l}\text { Future corporate performance is } \\
\text { also expected to have a negative } \\
\text { correlation with bankruptcy risk }\end{array}$ \\
\hline \multicolumn{4}{|c|}{ Independent Variables } \\
\hline $\begin{array}{l}\text { Bankruptcy risk-taking } \\
\text { propensity }\end{array}$ & Risk & Inverse of Altman Z-score & $\begin{array}{l}\text { An increase in bankruptcy risk is } \\
\text { expected to decrease the future ROA }\end{array}$ \\
\hline $\begin{array}{l}\text { Firm life cycle stages } \\
\text { interact with its } \\
\text { bankruptcy risk }\end{array}$ & FLCS*Risk & $\begin{array}{l}\text { Firms' different CLC stages, i.e., } \\
\text { introduction, growth, maturity, } \\
\text { and decline, interact with its } \\
\text { bankruptcy risk-taking propensity }\end{array}$ & $\begin{array}{c}\text { Insolvency risk propensity during } \\
\text { the introduction and growth stages } \\
\text { of the life cycle is expected to have } \\
\text { a positive association with future } \\
\text { corporate performance. However, } \\
\text { this relationship is predicted to be } \\
\text { negative for mature and decline } \\
\text { firms }\end{array}$ \\
\hline \multicolumn{4}{|c|}{ Firm-Level Control Variables } \\
\hline Firm size & SIZE & $\begin{array}{l}\text { Natural logarithm of the market } \\
\text { value of equity of firms }\end{array}$ & $\begin{array}{l}\text { A positive relationship is } \\
\text { anticipated between firm size and } \\
\text { its future performance }\end{array}$ \\
\hline Market to book ratio & МТВ & $\begin{array}{l}\text { Market value of equity/book value } \\
\text { of equity }\end{array}$ & $\begin{array}{l}\text { MTB is expected to have a positive } \\
\text { sign with future corporate } \\
\text { performance at different CLC stages }\end{array}$ \\
\hline Fixed assets growth rate & FAG & $\begin{array}{l}\text { Fixed assets growth is measured } \\
\text { as current years' fixed assets } \\
\text { scaled by lagged fixed assets }\end{array}$ & $\begin{array}{l}\text { Growth in fixed assets is expected to } \\
\text { generate better future performance }\end{array}$ \\
\hline \multicolumn{4}{|c|}{ Industry-Level Control Variable } \\
\hline Industry competition & INCOM & $\begin{array}{l}\text { Industry competition is measured } \\
\text { by the Herfindahl index. It is } \\
\text { calculated as the sum of the } \\
\text { squares of market share of firms } \\
\text { within a given industry. Higher } \\
\text { value of index suggests a high } \\
\text { market concentration and a low } \\
\text { level of competition }\end{array}$ & $\begin{array}{l}\text { An increase in competition is } \\
\text { anticipated to have negative effects } \\
\text { on a firm's ROA }\end{array}$ \\
\hline \multicolumn{4}{|c|}{ Country-Level Control Variables } \\
\hline Industrial growth rate & INGR & $\begin{array}{l}\text { Annual percentage increase in } \\
\text { industrial production of Pakistan }\end{array}$ & $\begin{array}{l}\text { Increased industrial growth is } \\
\text { expected to have a positive } \\
\text { association with future returns on } \\
\text { assets }\end{array}$ \\
\hline $\begin{array}{l}\text { Growth in Gross } \\
\text { domestic product }\end{array}$ & GDPG & Annual GDP growth rate & $\begin{array}{l}\text { GDP growth is also anticipated to } \\
\text { have a positive relationship with } \\
\text { future performance }\end{array}$ \\
\hline
\end{tabular}




\section{Appendix B}

Table A2. Variance inflation analysis.

\begin{tabular}{ccc}
\hline Variable & VIF & $\mathbf{1 / V I F}$ \\
\hline GDPG & 8.25 & 0.121252 \\
\hline SIZE & 7.10 & 0.140844 \\
\hline RISK & 5.12 & 0.195138 \\
\hline INGR & 4.81 & 0.207937 \\
\hline RISK ${ }^{*}$ Mature & 3.51 & 0.284604 \\
\hline INCOM & 2.26 & 0.443024 \\
\hline RISK*Intro & 1.84 & 0.542774 \\
\hline RISK ${ }^{*}$ Grow & 1.75 & 0.571160 \\
\hline MTB & 1.37 & 0.730724 \\
\hline RISK*Decline & 1.16 & 0.862375 \\
\hline FAG & 1.02 & 0.975757 \\
\hline Mean VIF & 3.47 & \\
\hline & &
\end{tabular}

\section{References}

1. Dickinson, V. Cash flow patterns as a proxy for firm life cycle. Account. Rev. 2011, 86, 1969-1994. [CrossRef]

2. Aghion, P.; Fally, T.; Scarpetta, S. Credit constraints as a barrier to the entry and post-entry growth of firms. Econ. Policy 2007, 22, 732-779. [CrossRef]

3. Miller, D.; Friesen, P.H. A longitudinal study of the corporate life cycle. Manag. Sci. 1984, 30, 1161-1183. [CrossRef]

4. Gray, B.; Ariss, S.S. Politics and strategic change across organizational life cycles. Acad. Manag. Rev. 1985, 10, 707-723. [CrossRef]

5. Canto-Cuevas, F.-J.; Palacín-Sánchez, M.-J.; Di Pietro, F. Trade Credit as a Sustainable Resource during an SME's Life Cycle. Sustainability 2019, 11, 670. [CrossRef]

6. Fitzsimmons, J.; Steffens, P.; Douglas, E. Growth and profitability in small and medium sized Australian firms. Growth and profitability in small and medium sized Australian firms. 2005. Available online: https: //papers.ssrn.com/sol3/papers.cfm?abstract_id=1263734 (accessed on 24 April 2020).

7. Akbar, A.; Akbar, M.; Tang, W.; Qureshi, M.A. Is Bankruptcy Risk Tied to Corporate Life-Cycle? Evidence from Pakistan. Sustainability 2019, 11, 678. [CrossRef]

8. Anthony, J.H.; Ramesh, K. Association between accounting performance measures and stock prices: A test of the life cycle hypothesis. J. Account. Econ. 1992, 15, 203-227. [CrossRef]

9. Richardson, S. Over-investment of free cash flow. Rev. Acc. Stud. 2006, 11, 159-189. [CrossRef]

10. DeAngelo, H.; DeAngelo, L.; Stulz, R.M. Dividend policy and the earned/contributed capital mix: A test of the life-cycle theory. J. Financ. Econ. 2006, 81, 227-254. [CrossRef]

11. Oude Avenhuis, J. Testing the Generalizability of the Bankruptcy Prediction Models of Altman, Ohlson and Zmijewski for Dutch Listed and Large Non-Listed Firms; University of Twente: Enschede, The Netherlands, 2013.

12. Rose-Ackerman, S. Risk taking and ruin: Bankruptcy and investment choice. J. Legal Stud. 1991, 20, $277-310$. [CrossRef]

13. Dichev, I.D. Is the risk of bankruptcy a systematic risk? J. Financ. 1998, 53, 1131-1147. [CrossRef]

14. Altman, E. Corporate Financial Distress and Bankruptcy; Wiley: New York, NY, USA, 1993.

15. Chang, H.; Feroz, E.; Bryan, D.; Fernando, G.D.; Tripathy, A. Bankruptcy risk, productivity and firm strategy. Rev. Acc. Financ. 2013, 12, 309-326.

16. DeAngelo, H.; DeAngelo, L. Dividend policy and financial distress: An empirical investigation of troubled NYSE firms. J. Financ. 1990, 45, 1415-1431. [CrossRef] 
17. Sudarsanam, S.; Lai, J. Corporate financial distress and turnaround strategies: An empirical analysis. Brit. J. Manag. 2001, 12, 183-199. [CrossRef]

18. Armour, H.O.; Teece, D.J. Organizational structure and economic performance: A test of the multidivisional hypothesis. Bell J. Econ. 1978, 106-122. [CrossRef]

19. Fisher, I.N.; Hall, G.R. Risk and corporate rates of return. Q. J. Econ. 1969, 79-92. [CrossRef]

20. Aaker, D.A.; Jacobson, R. The role of risk in explaining differences in profitability. Acad. Manag. J. 1987, 30, 277-296.

21. Fiegenbaum, A.; Thomas, H. An Examination of the Structural Stability of Boman's Risk-Return Paradox; Academy of Management Proceedings, Academy of Management: New York, NY, USA, 1985; pp. 7-10.

22. Bowman, E.H. A Risk/Return Paradox for Strategic Management; John Wiley \& Sons: Bristol, UK, 1980.

23. Bowman, E.H. Risk seeking by troubled firms. Sloan Manag. Rev. 1982, 23, 33.

24. Treacy, M.E.F. Profitability Patterns and Firm Size; Sloan School of Management: Cambridge, MA, USA, 1980.

25. Bowman, E.H. Content analysis of annual reports for corporate strategy and risk. Interfaces 1984, 14, 61-71. [CrossRef]

26. Andersen, T.J.; Denrell, J.; Bettis, R.A. Strategic responsiveness and Bowman's risk-return paradox. Strateg. Manag. J. 2007, 28, 407-429. [CrossRef]

27. Kirzner, I.M. Entrepreneurial discovery and the competitive market process: An Austrian approach. J. Econ. Lit. 1997, 35, 60-85.

28. Sørensen, J.B.; Stuart, T.E. Aging, obsolescence, and organizational innovation. Admin. Sci. Quart. 2000, 45, 81-112. [CrossRef]

29. Henderson, A.D.; Benner, M.J. The Evolution of Risk and Return in High-Velocity Settings; Academy of Management Best Paper Proceedings; Citeseer: New York, NY, USA, 2000.

30. Khan, M.; Watts, R.L. Estimation and empirical properties of a firm-year measure of accounting conservatism. J. Account. Econ. 2009, 48, 132-150. [CrossRef]

31. Amit, R.; Schoemaker, P.J. Strategic assets and organizational rent. Strateg. Manag. J. 1993, 14, $33-46$. [CrossRef]

32. Levie, J.; Lichtenstein, B.B. A terminal assessment of stages theory: Introducing a dynamic states approach to entrepreneurship. Entrep. Theory Pract. 2010, 34, 317-350. [CrossRef]

33. Habib, A.; Hasan, M.M.J.A. Firm life cycle, corporate risk-taking and investor sentiment. Account. Financ. 2017, 57, 465-497. [CrossRef]

34. Kahneman, D.; Tversky, A. Prospect theory: An analysis of decision under risk. Econometrica 1979, 47, 363-391. [CrossRef]

35. Bromiley, P. Testing a causal model of corporate risk taking and performance. Acad. Manag. J. 1991, 34, 37-59.

36. Liao, Y. The effect of fit between organizational life cycle and human resource management control on firm performance. J. Am. Acad. Bus. 2006, 8, 192-196.

37. Jaafar, H.; Halim, H.A. Refining the Firm Life Cycle Classification Method: A Firm Value Perspective. J. Econ. Bus. Manag. 2016, 4, 112-119. [CrossRef]

38. Navaretti, G.B.; Castellani, D.; Pieri, F. Age and firm growth: Evidence from three European countries. Small Bus. Econ. 2014, 43, 823-837. [CrossRef]

39. Selling, T.I.; Stickney, C.P. The effects of business environment and strategy on a firm's rate of return on assets. Financ. Anal. J. 1989, 45, 43-52. [CrossRef]

40. Yazdanfar, D.; Öhman, P. Life cycle and performance among SMEs: Swedish empirical evidence. J. Risk Financ. 2014, 15, 555-571. [CrossRef]

41. Lester, D.L.; Parnell, J.A. Firm size and environmental scanning pursuits across organizational life cycle stages. J. Small Bus. Enterp. Dev. 2008, 15, 540-554. [CrossRef]

42. Bulan, L.; Yan, Z. The pecking order of financing in the firm's life cycle. Bank. Financ. Lett. 2009, 1, $129-140$.

43. Chandler, A.D. Strategy and Structure; MIT Press: Cambridge, MA, USA, 1962.

44. Gort, M.; Klepper, S. Time paths in the diffusion of product innovations. Econ. J. 1982, 92, 630-653. [CrossRef]

45. Wernerfelt, B. The dynamics of prices and market shares over the product life cycle. Manag. Sci. 1985, 31, 928-939. [CrossRef]

46. Wang, Z.; Akbar, M.; Akbar, A. The Interplay between Working Capital Management and a Firm's Financial Performance across the Corporate Life Cycle. Sustainability 2020, 12, 1661. [CrossRef] 
47. Hasan, M.M.; Hossain, M.; Habib, A. Corporate life cycle and cost of equity capital. J. Contemp. Account. Econ. 2015, 11, 46-60. [CrossRef]

48. Benmelech, E.; Kandel, E.; Veronesi, P. Stock-Based Compensation and CEO (Dis) Incentives. Q. J. Econ. 2010, 125, 1769-1820. [CrossRef]

49. Cleary, S. The relationship between firm investment and financial status. J. Financ. 1999, 54, $673-692$. [CrossRef]

50. Griffin, J.M.; Lemmon, M.L. Book-to-market equity, distress risk, and stock returns. J. Financ. 2002, 57, 2317-2336. [CrossRef]

51. Altman, E.I. Financial ratios, discriminant analysis and the prediction of corporate bankruptcy. J. Financ. 1968, 23, 589-609. [CrossRef]

52. Springate, G.L. Predicting the Possibility of Failure in a Canadian Firm: A Discriminant Analysis; Simon Fraser University: Vancouver, BC, Canada, 1978.

53. Zmijewski, M.E. Methodological issues related to the estimation of financial distress prediction models. J. Account. Res. 1984, 59-82. [CrossRef]

54. Ohlson, J.A. Financial ratios and the probabilistic prediction of bankruptcy. J. Account. Res. 1980, $109-131$. [CrossRef]

55. Roomi, M.S.; Ahmad, W.; Ramzan, M.; Zia-ur-Rehman, M. Bankruptcy Prediction for Non-Financial Firms of Pakistan. Int. J. Account. Financ. Rep. 2015, 5, 26-37. [CrossRef]

56. Hussain, F.; Ali, I.; Ullah, S.; Ali, M. Can Altman Z-score Model Predict Business Failures in Pakistan? Evidence from Textile Companies of Pakistan. J. Econ. Sustain. Dev. 2014, 5, 110-115.

57. Awais, M.; Hayat, F.; Mehar, N.; Ul-Hassan, W. Do Z-Score and Current Ratio have Ability to Predict Bankruptcy? Dev. Country Stud. 2015, 5, 30-36.

58. Ijaz, M.S.; Hunjra, A.I. Assessing the Financial Failure Using Z-Score and Current Ratio: A Case of Sugar Sector Listed Companies of Karachi Stock Exchange. World Appl. Sci. J. 2013, 23, 863-870.

59. Almamy, J.; Aston, J.; Ngwa, L.N. An evaluation of Altman's Z-score using cash flow ratio to predict corporate failure amid the recent financial crisis: Evidence from the UK. J. Corp. Financ. 2016, 36, 278-285. [CrossRef]

60. Chouhan, V.; Chandra, B.; Goswami, S. Predicting financial stability of select BSE companies revisiting Altman Z score. Int. Lett. Soc. Hum. Sci. 2014, 15, 92-105. [CrossRef]

61. Hoque, M.; Bhandari, S.B.; Iyer, R. Predicting business failure using cash flow statement based measures. Manag. Financ. 2013, 39, 667-676.

62. Garson, G.D. Hierarchical Linear Modeling: Guide and Applications; Sage: Thousand Oaks, CA, USA, 2012.

63. Goldstein, H. Multilevel Statistical Models; John Wiley \& Sons: Bristol, UK, 2011; Volume 922.

64. Raudenbush, S.W.; Bryk, A.S. Hierarchical Linear Models: Applications and Data Analysis Methods; Sage: London, UK, 2002; Volume 1.

65. Hsiao, C. Benefits and limitations of panel data. Economet. Rev. 1985, 4, 121-174. [CrossRef]

66. Kennedy, P. Guide to Econometrics, 6th ed.; Wiley-Blackwell: Oxford, UK, 2008. 